\title{
Dementia Friendly Care: Methods to Improve Stakeholder Engagement and Decision Making
}

\author{
Anthea Innes (D) \\ Sarah Kate Smith \\ Sophie Bushell
}

Salford Institute for Dementia and Ageing, School of Health and Society,

University of Salford, Salford, UK
Correspondence: Anthea Innes

Salford Institute for Dementia and Ageing,

The Dementia Hub, School of Health and

Society, University of Salford, Salford, UK, M6 6PU

Tel +44016I 2952363

Email a.innes I@salford.ac.Uk

\begin{abstract}
Dementia friendly (DF) is a term that has been increasingly used in the international literature to describe approaches that include and involve people living with dementia within their communities and wider society. How to support the involvement of people living with dementia to achieve dementia friendly care or support outcomes is an area that has begun to receive attention. We begin by introducing the concept of dementia friendly, the policy context and what has already been evidenced via prior reviews and conceptual discussions. We conducted a systematic review following PRISMA guidelines, resulting in the inclusion of nineteen papers that reported on the methods and approaches used to involve people living with dementia in achieving dementia friendly or supportive care outcomes. Five primary themes were identified: the potential of group-based activities to facilitate inclusion and engagement; achieving engagement in decision making; the value of developing tools to help service providers to engage those living with dementia in care decisions; the role of awareness raising and education to support the inclusion of a range of stakeholders in achieving DF support and care outcomes; the need for cultural and contextual sensitivity when seeking to engage stakeholders to achieve positive care outcomes. We conclude by considering how both the underpinning ethos of social citizenship and social inclusion need to be in place alongside a range of approaches that are adapted to fit local contexts and needs to enable the involvement of people living with dementia in achieving dementia friendly care outcomes.
\end{abstract}

Keywords: people living with dementia, involvement, supportive communities, inclusive, social citizenship

\section{Introduction}

Global prevalence of dementia is high ( 50 million people currently) ${ }^{1}$ and is projected to double every two decades until $2050 .{ }^{2}$ Policy has set the directive to achieve outcomes that are "dementia friendly",3,4 with $\mathrm{UK}^{5}$ and international examples of dementia friendly initiatives now available. ${ }^{6}$ Dementia care is complex, and self-managing dementia and navigating dementia care is challenging; therefore what dementia friendly agendas mean for the practice of dementia care is similarly complex and challenging.

In the UK, the term dementia friendly was first used explicitly in government policy in $2012^{3}$ in the Prime Minister's Challenge on Dementia, where the creation of dementia friendly communities was stipulated as a government aim. Thirty countries have since been identified as working towards making their communities dementia friendly. ${ }^{7}$ In their review, Hebert and Scales ${ }^{8}$ identify many strands to what they term dementia friendly initiatives, including: dementia awareness 
education, environmental design and dementia friendly community developments. They identify both a lack of theory-based studies, although most research they reviewed appears to have person-centred principles underpinning the work, and also the relative absence of the views of people living with dementia in what is a developing and, as previously noted, a primarily qualitative research base. ${ }^{7}$ Importantly this paper does not focus solely on dementia friendly care and methods to include stakeholders, but on any initiative that could be considered to include "dementia friendly" elements of work. For this paper, stakeholders are people living with dementia, care partners (family members) and care commissioners and providers.

In a review of the concepts guiding dementia policy, via national plans, frameworks or strategies, Lin and Lewis ${ }^{9}$ identify three core concepts offering ways forward for dementia policy, practice and research. Two have emerged from policy directives, as already noted: Dementia Friendly from the UK government (although there are UK regional variations with Dementia Supportive preferred) and, from the US dementia action plan, Dementia Capable; Lin and Lewis ${ }^{9}$ add a third concept, Dementia Positive, that they coined from their review of the literature into the first two areas of work. The change in the language surrounding dementia is notable in the last decade ${ }^{8}$ and offers a roadmap towards what the World Health Organization and Alzheimer's Disease International ${ }^{10}$ called the normalization of dementia within society. Lin and Lewis ${ }^{9}$ argue that "dementia friendly" has at its heart a desire to include and involve those with lived experience of dementia, while "dementia capable" involves acknowledging dementia as a disability and mobilizing support and services to then promote the inclusion of people living with dementia in society as part of the disability inclusion movement. They argue that without the language of dementia positive, "defined as positivity towards dementia with an intentional emphasis on strength finding, manifesting through attitudes, beliefs, communications, and behaviors", then the goal of inclusion and normalization will be challenging to achieve. It is against this acknowledged backdrop of a change in focus and terminology, what we are calling "dementia friendly" in this paper, that our review is situated. We know that there is a change in policy directives, but what methods or techniques do we have knowledge of to achieve the involvement and inclusion of people living with dementia in the outcome of dementia friendly care or support? The focus on achieving outcomes for those living with dementia by applying the concept of dementia friendly to healthcare has been reviewed by Lin, ${ }^{7}$ who argues that the inclusion of those living with dementia is one way to achieve dementia friendly healthcare settings, as are environmental design and appropriate services. Our review focuses on the former, namely methods to ensure the inclusion of people living with dementia, as our aim is to explore the methods that can be used to achieve dementia friendly care outcomes.

It is important to also recognize the related literature that seeks to include people living with dementia. Supported decision making, or shared decision making, is one way people living with dementia can be enabled to direct their care and support needs and as such is an example of dementia friendly care in action and has been the subject of recent reviews. In their review, Wied et $\mathrm{al}^{11}$ found examples of methods and techniques to implement the policy directives of human rights via supported decision making. These include strategies that create a conducive environment for supported decision making and strategies that recognize the strengths and abilities of the person and avoid deficits (for example, times of day when the person is less cognitively alert). In this way this review demonstrates ways that the basic and fundamental principles of human rights declarations can be applied to support the decision-making processes in assessing and implementing the care and support needs of individuals with dementia. Similarly, the review by Geddis-Regan et $\mathrm{al}^{12}$ aimed to identify interventions to achieve shared decision making. They found limited examples relating to feeding decisions and advance care planning as well as studies that suggested techniques to enhance communication to enable shared decision making to occur. This is important, as emotion influences the everyday decision making of people living with dementia, yet another review ${ }^{13}$ found little evidence around how to help regulate emotion to enable decision making and promote the wishes of those with the diagnosis in everyday care decisions around social care planning and finances. While not focused on dementia friendly outcomes per se, these three reviews ${ }^{11-13}$ demonstrate the possibilities that finding ways to enable the involvement of people living with dementia in decision making may have for achieving DF care.

Another important area for achieving dementia friendly outcomes is maintaining social connections. In their review, Birt et $\mathrm{al}^{14}$ found that the support of others is required to enable the individual with dementia to maintain social connections and also through a range of personal strategies that individuals with dementia use to sustain their connections, including conforming to expected norms in social situations. In this way the social reserves and 
competencies of people with the diagnosis are required to navigate and maintain connections, but others can also help support this process. Thus, a key element of dementia friendly care is both recognizing the individual agency and strategies people with the diagnosis employ to achieve DF outcomes, but also the critical role others have in supporting this process. A scoping review ${ }^{15}$ demonstrates the possibilities, as yet under-researched and difficult to evaluate, that engaging in the arts may have for achieving what would be broadly aligned with "DF" outcomes for those living with dementia via social inclusion and connection.

Creativity has been discussed as a method to engage those living with dementia. Bellass et $\mathrm{al}^{16}$ have argued that creativity needs to be understood not just as partaking in traditional cultural arts practices but also as something that takes place in the everyday. This broader understanding of everyday creativity allows for new insights into the lives of people living with dementia while also advocating for relational approaches to creativity as opposed to "individual" approaches which can erase the relationship that the person has with their creative work.

The concept of social citizenship ${ }^{17}$ as a lens to understand dementia has gained increasing popularity in the movement towards advocacy and autonomy of people living with dementia. This shift in focus has been important and includes the individual's participation and inclusion in care, research and governance. Contributing to the development of a citizenship model from an organizational studies perspective, Baldwin and Greason ${ }^{18}$ discuss citizenship as a practice - something that is realized through action and in relationship to others. Introducing the concepts of midi- and micro-citizenship, the authors suggest a means to build citizenship alliances between people with dementia living in long-term care (LTC) facilities and front-line dementia care staff. ${ }^{18}$

Examples of involving people living with dementia/ stakeholders in research abound. ${ }^{19-23}$ These papers have highlighted several important issues relating to the increasing awareness of the importance of user involvement for dementia research. Challenges include finding ways to provide people living with dementia an equal opportunity to be involved, how to reach diverse groups of people living with dementia, how to provide the necessary support when we do reach those groups and how to maximize the potential of people with dementia to contribute towards research. ${ }^{23}$ Although the review papers we have contextualized our discussions within illustrate the plethora of evidence regarding people living with dementia and their effective involvement in research, examples of involving people living with dementia/stakeholders to achieve dementia friendly care are less obvious and more limited. This paper focuses on examples of methods and techniques to involve stakeholders, particularly people living with dementia, in achieving dementia friendly or dementia supportive care outcomes. We also build on key concepts that shape what might be considered dementia friendly, as well as the dementia friendly literature itself.

\section{Methods}

We conducted a systematic review following PRISMA guidelines. ${ }^{24}$ PRISMA seeks to improve the reporting of systematic reviews and meta-analyses through the use of checklists and flow diagrams (see Figure 1). The PRISMA checklist was used to explore the characteristics of each included study focused on the aims, methods, findings, conclusions as well as our consideration of the implications of the study for dementia friendly care or support outcomes. As this systematic review was not registered, we cannot provide a registration number. A review protocol was not prepared.

\section{Search Strategy}

Electronic databases, MEDLINE (Health Care Systems, Nursing databases), Cumulative Index to Nursing \& Allied Health Literature (CINAHL), PsycINFO (Psychology, Medicine, Psychiatry, Nursing, Sociology, Physiology and Linguistic databases), ProQuest Central (including Health and Medical, Social Sciences, Education and Humanities databases), OVID Online (Medical and Health Databases) were searched between 15th and 19th February 2021 using the search terms described in Table 1.

The search was limited to English-language studies published between 2000 and 2021. The rationale for the selected time period (2000-2021) was to capture any work prior to the time period of when the term dementia friendly became popular in policy and practice developments from 2009; however, very little work relating to dementia friendly was found before 2009. We used the terms Stakeholder Engagement OR User Involvement OR PPI in an attempt to reduce the vast quantities of original "hits" that appeared when using search terms like "participant" and "consumer". Specifically, "participant" gave rise to many papers involving research participants and not evidence of stakeholder 


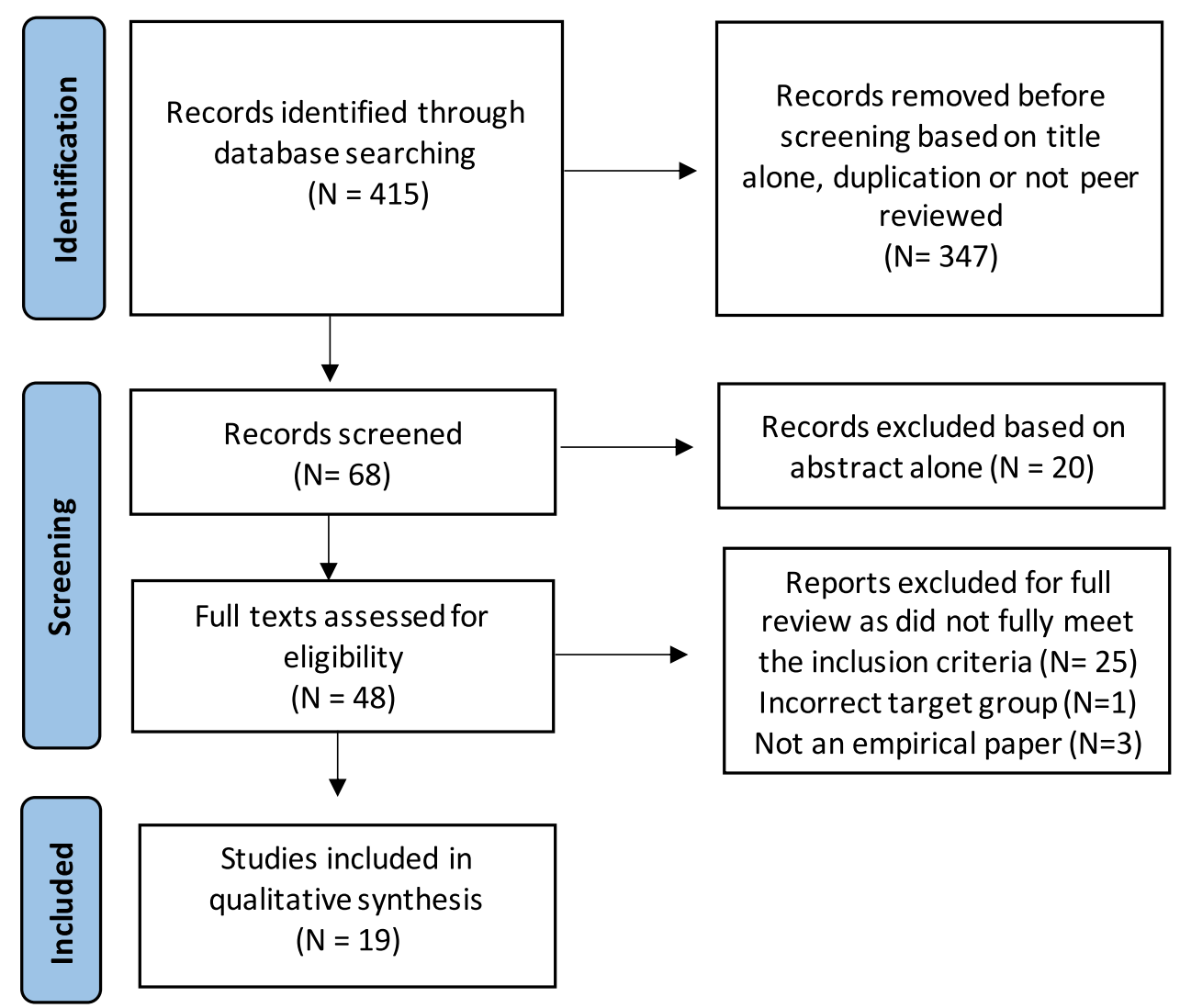

Figure I Flowchart displaying study selection according to PRISMA.

engagement or involvement which were essential search terms from the title for our review purposes.

\section{Inclusion Criteria}

Only published peer-reviewed original empirical articles were considered for inclusion. Excluded from review were dissertations, editorials, book chapters, book reviews, letters to

Table I Search Terms

\begin{tabular}{|l|l|}
\hline $\begin{array}{l}\text { Dementia OR Alzheimer's } \\
\text { disease (AD) }\end{array}$ & $\begin{array}{l}\text { NOT pharmacological OR drug } \\
\text { trials OR clinical evaluation/ } \\
\text { assessment OR neuroimaging }\end{array}$ \\
\hline $\begin{array}{l}\text { Stakeholder engagement OR } \\
\text { user involvement OR PPI }\end{array}$ & $\begin{array}{l}\text { NOT pharmacological OR drug } \\
\text { trials OR clinical evaluation/ } \\
\text { assessment OR neuroimaging }\end{array}$ \\
\hline $\begin{array}{l}\text { Dementia friendly care OR } \\
\text { dementia care OR dementia } \\
\text { friendly }\end{array}$ & NOT interventions for carers \\
\hline Decision making & NOT decision modelling \\
\hline $\begin{array}{l}\text { Social citizenship OR activism } \\
\text { OR human rights }\end{array}$ & $\begin{array}{l}\text { NOT animal rights OR drug } \\
\text { trials }\end{array}$ \\
\hline
\end{tabular}

editors, position papers, conceptual discussions and commentaries.

\section{Data Extraction}

After duplicates were removed, two reviewers (authors 1 and 2) conducted two independent screenings. First, the titles were screened, and then the abstracts of the remaining articles. Included papers for review were distributed equally between authors 1, 2 and 3 for data extraction. This third screening consisted mainly of one reviewer reading full-text articles (all three authors) with papers reviewed by a second member of the writing team when it was considered by the first allocated reviewer that the paper did not fit our inclusion criterion when read in full. This led to 6 fully reviewed papers being subsequently excluded. Extracted data were then verified by authors 1 and 2 and included details regarding the sample, study aims, setting/context, findings, conclusions and implications.

\section{Findings}

The database search resulted in 415 potentially relevant articles identified for review; 347 were immediately excluded based on title alone, duplication or not from 
peer-reviewed journals. Author 1 and 2 each reviewed half of the remaining 68 abstracts, and 20 further articles were excluded based on the abstract alone. After reviewing the abstracts, 48 full PDFs were extracted for review that met the inclusion criteria. Of the remaining 48 studies that met our inclusion criteria, 23 were further excluded from full review, as they did not meet the inclusion criteria. Twentyfive papers were fully reviewed, but on detailed reading a further six did not fully meet our criteria, thus the remaining nineteen studies are included in the present review that focus on dementia friendly care: methods to improve stakeholder engagement and decision making.

Table 2 presents the nineteen included studies that have been reviewed using 7 column headings: Lead Author and Date, Country and Setting, Methods and Participants, Aims, Findings, Conclusions and Implications for Future Involvement of People Living with Dementia (PLWD)/ Stakeholders to Achieve Dementia Friendly Care.

All studies included in the review focused on dementia friendly care and methods to involve stakeholders. Ten studies adopted a purely qualitative approach, ${ }^{25,27,30,33-35,38,39,41,42}$ with nine using mixed methods. ${ }^{26,28,29,31,32,36,37,40,43}$ The majority of articles $(n=12)^{25,27-30,33-35,37-39,42}$ included multiple stakeholders, including those living with dementia; there were three studies ${ }^{26,32,41}$ including only people living with dementia, and others solely focused on other stakeholders, for example employers $(n=1),{ }^{43}$ caregivers $(n=1)^{40}$ or health and social care professionals $(n=2))^{31,36}$ The papers reviewed were drawn primarily from Canada $(n=6),{ }^{25-29,41}$ and the UK $(n=5),{ }^{35,36,38,42,43}$ with others from Ireland $(n=2),{ }^{31,32}$ Australia $(n=2),{ }^{30,37}$ the USA $(n=1),{ }^{40}$ the Netherlands $(n=1),{ }^{33}$ Sweden $(n=1)^{34}$ and Taiwan $(n=1) .{ }^{39}$ Most studies $(n=15)^{25-27,29-31,33-35,37-40,42,43}$ focused on engaging and including those living in the community (which included two studies focusing on attending day provision or clinics within a hospital ${ }^{35,39}$ ), two studies focused on care homes settings ${ }^{28,32}$ and two focused on the hospital setting. ${ }^{36,41}$

A thematic analysis of the implications drawn from each paper (final column of Table 1) reviewed was undertaken. Author 1 identified the thematic areas, and authors 2 and 3 verified these. Five thematic areas emerged from our review.

\section{The Potential of Group-Based Activities to Facilitate Inclusion and Engagement}

Canadian-based studies exploring group-based activities demonstrated how social inclusion, social citizenship and partnership working principles could be enacted with reported positive benefits for those living with dementia $^{25-29}$ in terms of fostering feelings of belonging and value but also in day-to-day decision making and choices. Work by Theurer et $\mathrm{al}^{28}$ demonstrates how groups (a music group) have been developed for use in long-stay care settings that promote inclusion in creative ways, while the work of Dupuis et $\mathrm{al}^{25}$ for community-dwelling people living with dementia also demonstrates how participation in a creative group helps to challenge perceptions of a lack of ability by showcasing what is still possible while living with dementia. The study by Phinney et $\mathrm{al}^{27}$ exploring a community group for people living with dementia demonstrates the value of normal day-to-day activities in the neighbourhood to enable the enactment of social citizenship via interactions with neighbours, children and pets. The role people living with dementia can play in driving the direction of support is set out in the work of Wiersma et $\mathrm{al}^{29}$ and $\mathrm{Mann}^{26}$ who set up advisory hubs and an advisory group, respectively, where people living with dementia can work together to help agree and advocate for the direction of support they might need in the future. In these ways, groups offered a conduit to reaching principles that underpin dementia friendly care agendas.

\section{Achieving Engagement in Decision Making}

Five studies we reviewed recognized the importance of involvement in decision making about care to achieve positive DF outcomes. The Alzheimer Society of Canada Charter of Human Rights, developed with people living with dementia, ${ }^{26}$ demonstrates the desire for those with the dementia diagnosis to play an active part in all decision making relating to their lives and how by working in partnership together they can achieve collective advocacy to shape future decisions about dementia care. How to achieve shared decision making in practice can be challenging for care professionals. Examples of attempts to address this in care practice by professionals can be found in Australia, ${ }^{30}$ the Netherlands ${ }^{33}$ and Ireland. ${ }^{31,32}$ Groen-van de Ven et $\mathrm{al}^{33}$ found that shared decision making with people with dementia was possible, but that it required an adapted process. Giving potential service users and their families the opportunity of trying out services before committing to use them was one way of achieving this. In Ireland, ${ }^{32}$ steps to involve people living with dementia at home in their care planning decisions suggests that advocacy could have a useful role in helping social workers to take forward the expressed wishes of those 
Table 2 Summary of Papers Reviewed

\begin{tabular}{|c|c|c|c|c|c|c|}
\hline $\begin{array}{l}\text { Lead } \\
\text { Author and } \\
\text { Date }\end{array}$ & $\begin{array}{l}\text { Country } \\
\text { and Setting }\end{array}$ & $\begin{array}{l}\text { Methods and } \\
\text { Participants }\end{array}$ & Aim & Findings & Conclusions & $\begin{array}{l}\text { Implications for Future } \\
\text { Involvement of PLWD/ } \\
\text { Stakeholders to Achieve DFC }\end{array}$ \\
\hline $\begin{array}{l}\text { Bennett }{ }^{42} \\
2019\end{array}$ & $\begin{array}{l}\text { UK. } \\
\text { Diagnostic } \\
\text { clinic }\end{array}$ & $\begin{array}{l}\text { Qualitative, semi- } \\
\text { structured } \\
\text { interviews with } 14 \\
\text { participants (3 } \\
\text { specialist nurses, I } \\
\text { support worker, } 5 \\
\text { "patients“, } 5 \\
\text { "companions"). } \\
\text { Focus group } \\
\text { involving "service } \\
\text { recipients" (2 } \\
\text { PLWD), } 7 \text { "service } \\
\text { deliverers" } \\
\text { (managers, nurses, } \\
\text { support workers). }\end{array}$ & $\begin{array}{l}\text { To develop a tool } \\
\text { specific to dementia } \\
\text { diagnosis delivery. }\end{array}$ & $\begin{array}{l}\text { Experience of } \\
\text { diagnostic delivery } \\
\text { for PLWD and } \\
\text { clinicians reported. } \\
\text { Barriers to good } \\
\text { delivery were long } \\
\text { wait times and } \\
\text { rushed delivery. } \\
\text { Suggested } \\
\text { improvements were: } \\
\text { develop supportive } \\
\text { relationship, } \\
\text { promote choice, } \\
\text { develop } \\
\text { understanding, } \\
\text { provide emotional } \\
\text { support. } 2 \text { tools } \\
\text { were developed } \\
\text { including the PLWD } \\
\text { perspective to } \\
\text { support diagnostic } \\
\text { delivery. }\end{array}$ & $\begin{array}{l}\text { Provided insight into } \\
\text { the experience of } \\
\text { diagnostic delivery } \\
\text { for clinicians, PLWD } \\
\text { and CP. These tools } \\
\text { can help to improve } \\
\text { the diagnostic } \\
\text { delivery experience } \\
\text { of PLWD and } \\
\text { clinicians. }\end{array}$ & $\begin{array}{l}\text { Such tools might offer an } \\
\text { improved dementia diagnosis } \\
\text { process by encouraging and } \\
\text { supporting PLWD to prepare. } \\
\text { Such a process may be more } \\
\text { "dementia friendly" for all } \\
\text { involved. }\end{array}$ \\
\hline $\begin{array}{l}\text { Buckner }^{38} \\
2019\end{array}$ & $\begin{array}{l}\text { Dementia } \\
\text { friendly } \\
\text { communities } \\
\text { (DFC) across } \\
\text { England. }\end{array}$ & $\begin{array}{l}\text { Scoping study } \\
\text { involving } 284 \text { DFC } \\
\text { initiatives. }\end{array}$ & $\begin{array}{l}\text { To describe the } \\
\text { characteristics of } \\
\text { DFCs across } \\
\text { England to inform } \\
\text { a national evaluation } \\
\text { of their impact on } \\
\text { the lives of those } \\
\text { affected by } \\
\text { dementia. }\end{array}$ & $\begin{array}{l}\text { Among DFC } \\
\text { activities, awareness } \\
\text { raising was cited } \\
\text { most commonly, } \\
\text { some evidence of } \\
\text { involvement of } \\
\text { PLWD in } \\
\text { organizational and } \\
\text { operational aspects } \\
\text { of DFCs. } \\
\text { Approaches to } \\
\text { evaluation varied, } \\
\text { little evidence of } \\
\text { findings having } \\
\text { effected change. }\end{array}$ & $\begin{array}{l}\text { DFCs are } \\
\text { characterized by } \\
\text { variation in type, } \\
\text { resourcing and } \\
\text { activities. England } \\
\text { has policy } \\
\text { endorsement and } \\
\text { a recognition system } \\
\text { for DFCs. These can } \\
\text { be important } \\
\text { catalysts for } \\
\text { initiation and } \\
\text { growth. }\end{array}$ & $\begin{array}{l}\text { To gain a better understanding } \\
\text { there is a need to move beyond } \\
\text { description of what is "good" } \\
\text { DFCs to include different settings } \\
\text { and for different populations } \\
\text { (rather than consistent self- } \\
\text { selecting). }\end{array}$ \\
\hline $\begin{array}{l}\text { Donnelly } \\
2019\end{array}$ & $\begin{array}{l}\text { Ireland. } \\
\text { Involvement } \\
\text { of PLWD in } \\
\text { care planning. }\end{array}$ & $\begin{array}{l}\text { Online survey of } \\
\text { social workers } \\
\text { working with older } \\
\text { adults ( } n=38) \text {. In- } \\
\text { depth interviews } \\
\text { with social workers } \\
\text { ( } n=21) \text { (separate } \\
\text { cohort). } \\
\text { Social workers } \\
\text { working with older } \\
\text { adults ( } n=59) \text {. }\end{array}$ & $\begin{array}{l}\text { To explore how } \\
\text { older people with } \\
\text { dementia participate } \\
\text { in decision making } \\
\text { about their care. }\end{array}$ & $\begin{array}{l}\text { Predictors of care } \\
\text { involvement } \\
\text { amongst PLWD: } \\
\text { capacity, } \\
\text { paternalistic } \\
\text { approach from } \\
\text { family members, } \\
\text { need to balance risk } \\
\text { and autonomy } \\
\text { (family members and } \\
\text { professionals often } \\
\text { cautious and risk- } \\
\text { averse) } \\
\text { - SWs can be critical } \\
\text { advocates for } \\
\text { decision making. }\end{array}$ & $\begin{array}{l}\text { Supported decisions } \\
\text { will only become } \\
\text { reality if effective } \\
\text { systems are put in } \\
\text { place. PLWD should } \\
\text { be encouraged to } \\
\text { participate in } \\
\text { decision making } \\
\text { about their care. }\end{array}$ & $\begin{array}{l}\text { Advocacy offers opportunities for } \\
\text { PLWD to be involved in decision } \\
\text { making about their care and } \\
\text { support. Being dementia friendly is } \\
\text { about giving PLWD choice and } \\
\text { control, including choice and } \\
\text { control to take risks. }\end{array}$ \\
\hline
\end{tabular}

(Continued) 
Table 2 (Continued).

\begin{tabular}{|c|c|c|c|c|c|c|}
\hline $\begin{array}{l}\text { Lead } \\
\text { Author and } \\
\text { Date }\end{array}$ & $\begin{array}{l}\text { Country } \\
\text { and Setting }\end{array}$ & $\begin{array}{l}\text { Methods and } \\
\text { Participants }\end{array}$ & Aim & Findings & Conclusions & $\begin{array}{l}\text { Implications for Future } \\
\text { Involvement of PLWD/ } \\
\text { Stakeholders to Achieve DFC }\end{array}$ \\
\hline $\begin{array}{l}\text { Dupuis }^{25} \\
2016\end{array}$ & $\begin{array}{l}\text { Canada. } \\
\text { Community- } \\
\text { based, critical } \\
\text { arts project. }\end{array}$ & $\begin{array}{l}\text { Creation of } \\
\text { a research-based } \\
\text { drama challenging } \\
\text { the tragedy } \\
\text { discourse of } \\
\text { dementia. } \\
\text { Focus groups and } \\
\text { artistic reflection } \\
\text { co-created with } \\
\text { PLWD. Telephone } \\
\text { interviews } \\
\text { PLWD ( } n=8) \text {, family } \\
\text { members ( } n=7) \text {, } \\
\text { performance artists } \\
(n=15) \text {, researchers } \\
(n=7) \text {. }\end{array}$ & $\begin{array}{l}\text { To provide PLWD } \\
\text { a creative } \\
\text { opportunity to } \\
\text { challenge dominant } \\
\text { and oppressive } \\
\text { master narratives. } \\
\text { Enable the } \\
\text { emergence of } \\
\text { emancipatory } \\
\text { stories. }\end{array}$ & $\begin{array}{l}\text { Narrative citizenship } \\
\text { offers an informative } \\
\text { way to fashion new } \\
\text { discourse of } \\
\text { citizenship and } \\
\text { dementia. }\end{array}$ & $\begin{array}{l}\text { When PLWD were } \\
\text { able to interrogate } \\
\text { negative discourse, } \\
\text { stigma and } \\
\text { stereotypes their } \\
\text { meaning lost } \\
\text { significance and } \\
\text { opened up } \\
\text { alternative } \\
\text { discourses of } \\
\text { possibilities through } \\
\text { mutual story telling. }\end{array}$ & $\begin{array}{l}\text { Using drama to challenge the } \\
\text { negative discourse of dementia. } \\
\text { This approach has the potential to } \\
\text { be used in a wider context in the } \\
\text { community. }\end{array}$ \\
\hline Egdell $^{43} 2021$ & $\begin{array}{l}\text { Scotland UK. } \\
\text { Employers' } \\
\text { perspectives. }\end{array}$ & $\begin{array}{l}331 \text { responses to } \\
\text { online employers' } \\
\text { survey and } 30 \\
\text { follow-up employer } \\
\text { interviews. }\end{array}$ & $\begin{array}{l}\text { Employers' views on } \\
\text { dementia as } \\
\text { a workplace concern } \\
\text { and the policies and } \\
\text { practices available to } \\
\text { support human } \\
\text { rights agendas for } \\
\text { PLWD. }\end{array}$ & $\begin{array}{l}\text { Dementia awareness } \\
\text { was found, but this } \\
\text { knowledge was not } \\
\text { applied to } \\
\text { employment } \\
\text { situations. Lack of } \\
\text { evidence that the } \\
\text { rights of employees } \\
\text { living with dementia } \\
\text { are consistently } \\
\text { upheld. }\end{array}$ & $\begin{array}{l}\text { The rights and legal } \\
\text { position of working } \\
\text { age PLWD need } \\
\text { addressing as they } \\
\text { are consistently not } \\
\text { recognized. }\end{array}$ & $\begin{array}{l}\text { There is a lack of application of } \\
\text { awareness of dementia to the } \\
\text { workplace setting, and therefore } \\
\text { training for employers is needed } \\
\text { to support future action. }\end{array}$ \\
\hline $\begin{array}{l}\text { Goeman }^{30} \\
2019\end{array}$ & $\begin{array}{l}\text { Australia. } \\
\text { Community } \\
\text { setting. }\end{array}$ & $\begin{array}{l}\text { Evaluation study, } \\
\text { expert working } \\
\text { group and reference } \\
\text { group of unspecified } \\
\text { numbers of people } \\
\text { living with dementia } \\
\text { and care partners, } \\
\text { aged care service } \\
\text { providers, } \\
\text { policymakers; and } \\
\text { academics. }\end{array}$ & $\begin{array}{l}\text { To describe the co- } \\
\text { design process. }\end{array}$ & $\begin{array}{l}\text { The development of } \\
\text { a successful co- } \\
\text { design process that } \\
\text { includes PLWD and } \\
\text { care partners at all } \\
\text { stages of the } \\
\text { research process } \\
\text { and addresses their } \\
\text { individual needs. }\end{array}$ & $\begin{array}{l}\text { Co-design provides } \\
\text { support for } \\
\text { community-dwelling } \\
\text { people to be } \\
\text { involved in the } \\
\text { research design, } \\
\text { dissemination and } \\
\text { implementation of } \\
\text { the findings. }\end{array}$ & $\begin{array}{l}\text { Involving PLWD and care partners } \\
\text { in co-designing research projects } \\
\text { ensures that services/models/ } \\
\text { future research reflect the } \\
\text { expressed views and opinions of } \\
\text { the consumers. }\end{array}$ \\
\hline Grace $^{37} 2018$ & $\begin{array}{l}\text { Australia. } \\
\text { Social group. }\end{array}$ & $\begin{array}{l}\text { Co-designed } \\
\text { workshops to } \\
\text { develop dementia } \\
\text { support toolkit. } \\
\text { Involved } 8 \text { PLWD } \\
\text { and carers, I3 } \\
\text { members of local } \\
\text { older people social } \\
\text { groups and } 22 \text { local } \\
\text { GPs and other } \\
\text { health-service } \\
\text { providers. }\end{array}$ & $\begin{array}{l}\text { To evaluate } \\
\text { a dementia health } \\
\text { literacy project. }\end{array}$ & $\begin{array}{l}\text { A dementia support } \\
\text { kit was produced to } \\
\text { provide locally } \\
\text { relevant and useful } \\
\text { information for } \\
\text { people with } \\
\text { dementia and their } \\
\text { carers. }\end{array}$ & $\begin{array}{l}\text { Co-design is } \\
\text { a valuable approach } \\
\text { to producing and } \\
\text { disseminating } \\
\text { dementia health } \\
\text { literacy resources. }\end{array}$ & $\begin{array}{l}\text { Such tools may have implications } \\
\text { for future behaviours and health } \\
\text { outcomes. }\end{array}$ \\
\hline
\end{tabular}

(Continued) 
Table 2 (Continued).

\begin{tabular}{|c|c|c|c|c|c|c|}
\hline $\begin{array}{l}\text { Lead } \\
\text { Author and } \\
\text { Date }\end{array}$ & $\begin{array}{l}\text { Country } \\
\text { and Setting }\end{array}$ & $\begin{array}{l}\text { Methods and } \\
\text { Participants }\end{array}$ & Aim & Findings & Conclusions & $\begin{array}{l}\text { Implications for Future } \\
\text { Involvement of PLWD/ } \\
\text { Stakeholders to Achieve DFC }\end{array}$ \\
\hline $\begin{array}{l}\text { Groen-Van } \\
\text { De Ven } \\
2017\end{array}$ & $\begin{array}{l}\text { Netherlands. } \\
\text { Community } \\
\text { settings and } \\
\text { nursing } \\
\text { homes. }\end{array}$ & $\begin{array}{l}\text { Qualitative, } \\
\text { prospective, multi- } \\
\text { perspective, via } 244 \\
\text { interviews } \\
19 \text { people with } \\
\text { dementia (early- } \\
\text { moderate), } 36 \text { of } \\
\text { their informal } \\
\text { caregivers and } 38 \text { of } \\
\text { their professionals } \\
\text { (including } \\
\text { nurses, day-care } \\
\text { employees and case } \\
\text { managers). }\end{array}$ & $\begin{array}{l}\text { To explore how } \\
\text { people with } \\
\text { dementia, their } \\
\text { informal caregivers } \\
\text { and professionals } \\
\text { participate in } \\
\text { decision making } \\
\text { about day-care and } \\
\text { to develop } \\
\text { a typology of } \\
\text { participation } \\
\text { trajectories. }\end{array}$ & $\begin{array}{l}\text { Critical points were } \\
\text { expectations of day- } \\
\text { care, negotiating } \\
\text { trying out day-care, } \\
\text { trying out day-care. } \\
\text { Participatory } \\
\text { trajectories were } \\
\text { working together } \\
\text { positively } \\
\text { towards day-care, } \\
\text { bringing conflicting } \\
\text { perspectives } \\
\text { together to facilitate } \\
\text { trying out day-care } \\
\text { and not reaching } \\
\text { a commitment to try } \\
\text { out day-care. }\end{array}$ & $\begin{array}{l}\text { Shared decision } \\
\text { making with people } \\
\text { with dementia is } \\
\text { possible and } \\
\text { requires an adapted } \\
\text { process of decision } \\
\text { making; trying out } \\
\text { services one way of } \\
\text { achieving this. }\end{array}$ & $\begin{array}{l}\text { Finding ways for people to "try } \\
\text { out" care solutions can enhance } \\
\text { involvement in decision making } \\
\text { and DFC outcomes. }\end{array}$ \\
\hline Guest $^{40} 2021$ & $\begin{array}{l}\text { South } \\
\text { Carolina, } \\
\text { USA. } \\
\text { Caregivers } \\
\text { providing } \\
\text { support to } \\
\text { people living } \\
\text { in the } \\
\text { community. }\end{array}$ & $\begin{array}{l}\text { I48 African- } \\
\text { American caregivers } \\
\text { participated in } \\
\text { education } \\
\text { intervention, were } \\
\text { trained and } \\
\text { completed pre- and } \\
\text { post-test } \\
\text { questionnaire. } \\
34 \text { were } \\
\text { interviewed. }\end{array}$ & $\begin{array}{l}\text { To evaluate the } \\
\text { impact of a pilot } \\
\text { education } \\
\text { programme - In Our } \\
\text { Community, } \\
\text { Dementia Speaks. }\end{array}$ & $\begin{array}{l}\text { Information on } \\
\text { caregiver practice, } \\
\text { caregiver strategies, } \\
\text { caregiver quality of } \\
\text { life and patient } \\
\text { quality of life. }\end{array}$ & $\begin{array}{l}\text { Community } \\
\text { members reported } \\
\text { the programme } \\
\text { a success in further } \\
\text { engaging African- } \\
\text { American caregivers } \\
\text { of individuals living } \\
\text { with dementia and } \\
\text { the need for the } \\
\text { programme to be } \\
\text { revised and } \\
\text { expanded. }\end{array}$ & $\begin{array}{l}\text { Cultural norms are important - } \\
\text { tailoring an education intervention } \\
\text { is one way of engaging more family } \\
\text { caregivers. }\end{array}$ \\
\hline Mann ${ }^{26} 2020$ & $\begin{array}{l}\text { Canadian } \\
\text { charter of } \\
\text { rights for } \\
\text { people living } \\
\text { with } \\
\text { dementia. }\end{array}$ & $\begin{array}{l}\text { Conversations } \\
\text { amongst Alzheimer } \\
\text { Society of Canada's } \\
\text { advisory group } \\
\text { members (PLWD 8). }\end{array}$ & $\begin{array}{l}\text { Aim to create } \\
\text { a charter to be } \\
\text { a tool to challenge } \\
\text { stigma and increase } \\
\text { awareness of } \\
\text { dementia and its } \\
\text { links to human } \\
\text { rights. }\end{array}$ & $\begin{array}{l}\text { Charter of rights: } \\
\text { To be free from } \\
\text { discrimination of any } \\
\text { kind. To benefit from } \\
\text { Canada's civil and } \\
\text { legal rights. } \\
\text { To get information } \\
\text { and support to } \\
\text { participate fully in } \\
\text { decisions. }\end{array}$ & $\begin{array}{l}\text { The rights of PLWD } \\
\text { should be } \\
\text { recognized, and } \\
\text { people (such as } \\
\text { medical teams and } \\
\text { care staff) should be } \\
\text { made aware of this } \\
\text { charter. }\end{array}$ & $\begin{array}{l}\text { Demonstrates that PLWD can } \\
\text { work together to advocate for } \\
\text { their own rights if provided with } \\
\text { appropriate support. }\end{array}$ \\
\hline $\begin{array}{l}\text { Mayrhofer }{ }^{35} \\
2018\end{array}$ & $\begin{array}{l}\text { Community- } \\
\text { based } \\
\text { services in } 2 \\
\text { UK sites. }\end{array}$ & $\begin{array}{l}\text { Discussion groups } \\
\text { with PLWD, } \\
\text { interviews with } \\
\text { memory services } \\
\text { and other service } \\
\text { providers. } \\
\text { Involved 3I PLWD, } 3 \\
\text { memory services } \\
\text { and } 7 \text { local service } \\
\text { providers. }\end{array}$ & $\begin{array}{l}\text { To understand } \\
\text { priorities for service } \\
\text { planning and } \\
\text { commissioning. }\end{array}$ & $\begin{array}{l}\text { Discussions } \\
\text { confirmed published } \\
\text { evidence on support } \\
\text { requirements, but } \\
\text { also reframed } \\
\text { priorities for } \\
\text { support and } \\
\text { suggested new } \\
\text { approaches to } \\
\text { dementia care at the } \\
\text { community level. }\end{array}$ & $\begin{array}{l}\text { Involving people } \\
\text { with young-onset } \\
\text { dementia in the } \\
\text { assessment of } \\
\text { research findings } \\
\text { provides a future } \\
\text { way for co-designing } \\
\text { accessible services. }\end{array}$ & $\begin{array}{l}\text { People living with young-onset } \\
\text { dementia can provide critical } \\
\text { opinions and perspectives on } \\
\text { research findings, service } \\
\text { provision and future policy and } \\
\text { research priorities. How to } \\
\text { develop this approach is key. }\end{array}$ \\
\hline
\end{tabular}

(Continued) 
Table 2 (Continued).

\begin{tabular}{|c|c|c|c|c|c|c|}
\hline $\begin{array}{l}\text { Lead } \\
\text { Author and } \\
\text { Date }\end{array}$ & $\begin{array}{l}\text { Country } \\
\text { and Setting }\end{array}$ & $\begin{array}{l}\text { Methods and } \\
\text { Participants }\end{array}$ & Aim & Findings & Conclusions & $\begin{array}{l}\text { Implications for Future } \\
\text { Involvement of PLWD/ } \\
\text { Stakeholders to Achieve DFC }\end{array}$ \\
\hline $\begin{array}{l}\text { Morgan- } \\
\text { Brown }^{32} \\
2018\end{array}$ & $\begin{array}{l}\text { Ireland. } \\
\text { Care homes. }\end{array}$ & $\begin{array}{l}\text { Observational study } \\
\text { design in } 5 \text { long-stay } \\
\text { residential units } \\
\text { involving } 73 \text { PWLD, } \\
\text { recording engaged } \\
\text { and non-engaged } \\
\text { behaviours using an } \\
\text { audit tool. }\end{array}$ & $\begin{array}{l}\text { Evaluation of the } \\
\text { Assessment Tool for } \\
\text { Occupational and } \\
\text { Social Engagement } \\
\text { (ATOSE) and } \\
\text { development of } \\
\text { definition of minimal } \\
\text { acceptable levels of } \\
\text { resident } \\
\text { engagement. }\end{array}$ & $\begin{array}{l}\text { Low levels of } \\
\text { engagement } \\
\text { amongst PLWD in } \\
\text { communal areas of } \\
\text { residential care. } \\
\text { ATOSE provided } \\
\text { a simple-to-use } \\
\text { assessment of } \\
\text { engagement and can } \\
\text { be used as an audit } \\
\text { tool to assess } \\
\text { engagement. }\end{array}$ & $\begin{array}{l}\text { Highlights the needs } \\
\text { and the human } \\
\text { rights of residents } \\
\text { with dementia to } \\
\text { engage in everyday } \\
\text { occupations and } \\
\text { social networks. }\end{array}$ & $\begin{array}{l}\text { Not only are there implications } \\
\text { for the rights and needs to engage } \\
\text { and involve people living with } \\
\text { dementia in care homes, but also } \\
\text { there is a lack of tools to measure } \\
\text { whether attempts to do so are } \\
\text { successful. }\end{array}$ \\
\hline $\begin{array}{l}\text { Österholm }{ }^{34} \\
2016\end{array}$ & $\begin{array}{l}\text { Sweden. } \\
\text { In clients' } \\
\text { own homes. }\end{array}$ & $\begin{array}{l}\text { Qualitative analysis } \\
\text { of transcripts from } \\
\text { II PLWD, } \\
\text { assessment meetings } \\
\text { with social worker } \\
\text { alongside } \\
\text { complementary } \\
\text { ethnographic field } \\
\text { notes. }\end{array}$ & $\begin{array}{l}\text { Investigate ways } \\
\text { PLWD practise their } \\
\text { citizenship in } \\
\text { assessment meetings } \\
\text { with social workers. }\end{array}$ & $\begin{array}{l}\text { Participation of } \\
\text { PLWD in assessment } \\
\text { meetings varies. } \\
\text { Communication } \\
\text { problems occurred } \\
\text { in all II meetings, } \\
\text { eg, word finding, } \\
\text { understanding and } \\
\text { making use of } \\
\text { information. Other } \\
\text { difficulties included } \\
\text { keeping up with } \\
\text { conversation, } \\
\text { remembering } \\
\text { previous happenings } \\
\text { and repetition. }\end{array}$ & $\begin{array}{l}\text { An individual's } \\
\text { dementia may affect } \\
\text { their ability to } \\
\text { contribute to } \\
\text { assessment meetings } \\
\text { and thereby } \\
\text { practise their } \\
\text { citizenship. }\end{array}$ & $\begin{array}{l}\text { Further studies are needed to } \\
\text { look at communication styles } \\
\text { amongst social workers and see if } \\
\text { and how using alternative styles } \\
\text { can promote participation. }\end{array}$ \\
\hline Parke $^{41} 2017$ & $\begin{array}{l}\text { Canada. } \\
\text { Hospital } \\
\text { settings. }\end{array}$ & $\begin{array}{l}\text { Exploratory iterative } \\
\text { design utilizing } \\
\text { scoping literature } \\
\text { review methodology } \\
\text { exploring DF design. }\end{array}$ & $\begin{array}{l}\text { To report the } \\
\text { findings of } \\
\text { a knowledge } \\
\text { synthesis research } \\
\text { project on the topic } \\
\text { of dementia friendly } \\
\text { acute care (D-FAC) } \\
\text { design. }\end{array}$ & $\begin{array}{l}\text { Confirms the limited } \\
\text { nature of available } \\
\text { acute care design } \\
\text { evidence on } \\
\text { maximizing function. }\end{array}$ & $\begin{array}{l}\text { Physical design } \\
\text { influences the } \\
\text { usability and activity } \\
\text { undertaken in } \\
\text { a health care space } \\
\text { and ultimately affects } \\
\text { patient outcomes. }\end{array}$ & $\begin{array}{l}\text { Knowledge about how design } \\
\text { influences PLWD in hospital } \\
\text { spaces is still lacking. Even more } \\
\text { can be learnt from PLWD } \\
\text { themselves, but this is not } \\
\text { indicated in this review. }\end{array}$ \\
\hline $\begin{array}{l}\text { Phinney } \\
2016\end{array}$ & $\begin{array}{l}\text { Canada (BC). } \\
\text { Community } \\
\text { group (social/ } \\
\text { leisure) for } \\
\text { younger } \\
\text { people (Paul's } \\
\text { group). }\end{array}$ & $\begin{array}{l}\text { Ethnographic: } 400+ \\
\text { hours of participant } \\
\text { observation over } 58 \\
\text { sessions, fieldnotes/ } \\
\text { go-along (walking) } \\
\text { interviews, walking } \\
\text { vignettes/FG and } \\
\text { data from family } \\
\text { member interviews; } \\
\text { 12-I5 PLWD. }\end{array}$ & $\begin{array}{l}\text { To explore how } \\
\text { community-based } \\
\text { programming can } \\
\text { promote social } \\
\text { citizenship for } \\
\text { people with } \\
\text { dementia. }\end{array}$ & $\begin{array}{l}\text { The group, } \\
\text { particularly the } \\
\text { walking excursions, } \\
\text { is an act of social } \\
\text { citizenship by: } \\
\text { I. Keeping the focus } \\
\text { off dementia; } 2 \text {. } \\
\text { Creating a place of } \\
\text { belonging; and } \\
\text { 3. Claiming a place in } \\
\text { the community. }\end{array}$ & $\begin{array}{l}\text { A focus on "normal" } \\
\text { leisure-based } \\
\text { activities within the } \\
\text { community in } \\
\text { a natural way. } \\
\text { Focusing on what } \\
\text { people can and want } \\
\text { to do enables social } \\
\text { citizenship to be } \\
\text { enacted in the } \\
\text { community. } \\
\text { Positioning, } \\
\text { participation and } \\
\text { community key } \\
\text { concepts. }\end{array}$ & $\begin{array}{l}\text { Offers a way to contribute to DF } \\
\text { communities through involvement } \\
\text { and enacting of social citizenship } \\
\text { via engaging within the local } \\
\text { community walkways. Suggests an } \\
\text { alternative to traditional care } \\
\text { provided by health and social care } \\
\text { professionals to enable the } \\
\text { involvement and inclusion of } \\
\text { people with dementia (who are } \\
\text { relatively well and physically able). }\end{array}$ \\
\hline
\end{tabular}

(Continued) 
Table 2 (Continued).

\begin{tabular}{|c|c|c|c|c|c|c|}
\hline $\begin{array}{l}\text { Lead } \\
\text { Author and } \\
\text { Date }\end{array}$ & $\begin{array}{l}\text { Country } \\
\text { and Setting }\end{array}$ & $\begin{array}{l}\text { Methods and } \\
\text { Participants }\end{array}$ & Aim & Findings & Conclusions & $\begin{array}{l}\text { Implications for Future } \\
\text { Involvement of PLWD/ } \\
\text { Stakeholders to Achieve DFC }\end{array}$ \\
\hline $\begin{array}{l}\text { Theurer }^{28} \\
2014\end{array}$ & $\begin{array}{l}\text { Canada (BC). } \\
3 \text { long-term } \\
\text { care homes } \\
\text { (LTCH), Java } \\
\text { music club } \\
\text { (mutual } \\
\text { support } \\
\text { group). }\end{array}$ & $\begin{array}{l}\text { Mixed-methods } \\
\text { qualitative process } \\
\text { evaluation design: } \\
\text { focus groups, } \\
\text { systematic } \\
\text { observation of six } \\
\text { resident groups, } \\
\text { individual resident } \\
\text { interviews ( } n=65) \\
\text { and staff interviews } \\
(n=7) \text { of those } \\
\text { involved in the Java } \\
\text { music group. }\end{array}$ & $\begin{array}{l}\text { To present and } \\
\text { describe a rationale } \\
\text { for an intervention } \\
\text { involving mutual } \\
\text { support groups in } \\
\text { LTCH; to evaluate } \\
\text { its process, } \\
\text { structure and } \\
\text { content; and to } \\
\text { provide evidence } \\
\text { that supports } \\
\text { refinement and } \\
\text { replication. Based on } \\
\text { enacting Kitwood } \\
\text { model of } \\
\text { personhood. }\end{array}$ & $\begin{array}{l}\text { Group structure } \\
\text { fosters active } \\
\text { participation of } \\
\text { residents with } \\
\text { moderate-severe } \\
\text { cognitive } \\
\text { impairment. }\end{array}$ & $\begin{array}{l}\text { This preliminary } \\
\text { study suggests that } \\
\text { mutual support } \\
\text { groups (in this case } \\
\text { a music-based } \\
\text { group) have } \\
\text { potential to offset } \\
\text { loneliness, } \\
\text { helplessness and } \\
\text { depression within } \\
\text { LTCH. Also } \\
\text { increases } \\
\text { opportunities for } \\
\text { the voices of people } \\
\text { with dementia in } \\
\text { LTCH to be heard } \\
\text { and for the focus } \\
\text { and direction to be } \\
\text { based on resident } \\
\text { wishes rather than } \\
\text { staff. }\end{array}$ & $\begin{array}{l}\text { Mutual support groups (based on } \\
\text { the Java music group model) } \\
\text { provide a way to achieve dementia } \\
\text { friendly care outcomes by } \\
\text { increasing self-determination } \\
\text { by taking on leadership and making } \\
\text { choices; increasing giving and } \\
\text { receiving help, increased focus on } \\
\text { inner strengths, beliefs and } \\
\text { abilities, strengthen supportive } \\
\text { relationships with one another } \\
\text { and to increase expression of } \\
\text { challenges faced allowing } \\
\text { interpretations. }\end{array}$ \\
\hline $\begin{array}{l}\text { Waller }{ }^{36} \\
2017\end{array}$ & $\begin{array}{l}\text { UK. } \\
\text { NHS Trusts. }\end{array}$ & $\begin{array}{l}\text { Development, use } \\
\text { and review of } \\
\text { environmental } \\
\text { assessment tools in } \\
\text { hospital wards, care } \\
\text { homes, health } \\
\text { centres and housing } \\
\text { with care. }\end{array}$ & $\begin{array}{l}\text { To develop more } \\
\text { supportive design } \\
\text { for people with } \\
\text { dementia in } \\
\text { hospitals. }\end{array}$ & $\begin{array}{l}10,000 \text { copies of the } \\
\text { tools have been } \\
\text { downloaded, for use } \\
\text { in hospitals, care } \\
\text { homes and hospices } \\
\text { across the UK, } \\
\text { Australia, } \\
\text { Scandinavia, Holland, } \\
\text { Germany, Brazil, } \\
\text { Canada and the } \\
\text { USA. }\end{array}$ & $\begin{array}{l}\text { Using the tools led } \\
\text { to securing finance } \\
\text { to make } \\
\text { environmental } \\
\text { changes. The tools } \\
\text { were valued in } \\
\text { supporting } \\
\text { attitudinal change } \\
\text { and enabling DF } \\
\text { design in } \\
\text { refurbishment. }\end{array}$ & $\begin{array}{l}\text { The authors imply that getting } \\
\text { physical design right for people } \\
\text { with dementia is also likely to } \\
\text { enhance the experience of those } \\
\text { who live, work and visit a care } \\
\text { environment. }\end{array}$ \\
\hline $\begin{array}{l}\text { Wiersma } \\
2016\end{array}$ & $\begin{array}{l}\text { Canada. } \\
\text { Community. }\end{array}$ & $\begin{array}{l}\text { Participatory action } \\
\text { research (PAR) using } \\
3 \text { advisory hubs. } 3 \\
\text { hubs comprising } 20 \\
\text { people with } \\
\text { dementia, } 13 \text { care } \\
\text { partners and } 3 \\
\text { service providers, in } \\
3 \text { locations across } \\
\text { Canada. }\end{array}$ & $\begin{array}{l}\text { To develop a self- } \\
\text { management } \\
\text { programme for } \\
\text { people with } \\
\text { dementia (grounded } \\
\text { by a citizenship lens). }\end{array}$ & $\begin{array}{l}\text { Group composition } \\
\text { was important (to } \\
\text { include care } \\
\text { partners or not). } 4 \\
\text { themes around this } \\
\text { core issue: creating } \\
\text { safe spaces; } \\
\text { maintaining voice } \\
\text { and being heard; } \\
\text { managing the } \\
\text { balancing act; and } \\
\text { the importance of } \\
\text { solidarity. A fifth } \\
\text { theme, the } \\
\text { recognition that } \\
\text { "one size doesn't fit } \\
\text { all“. }\end{array}$ & $\begin{array}{l}\text { Participating in } \\
\text { groups with other } \\
\text { PLWD can be } \\
\text { liberating, } \\
\text { empowering and } \\
\text { build confidence, } \\
\text { providing } \\
\text { opportunities for } \\
\text { growth, change and } \\
\text { development. } \\
\text { A focus on "living } \\
\text { well" and "self- } \\
\text { management", } \\
\text { a sense of solidarity } \\
\text { with others can be } \\
\text { transformative. }\end{array}$ & $\begin{array}{l}\text { To support social citizenship (an } \\
\text { outcome of DFC) of people with } \\
\text { dementia, researchers and } \\
\text { practitioners must pay attention } \\
\text { to these dynamics between people } \\
\text { with dementia and care partners } \\
\text { and understand the implications of } \\
\text { groups participating separately or } \\
\text { together. }\end{array}$ \\
\hline
\end{tabular}

(Continued) 
Table 2 (Continued).

\begin{tabular}{|c|c|c|c|c|c|c|}
\hline $\begin{array}{l}\text { Lead } \\
\text { Author and } \\
\text { Date }\end{array}$ & $\begin{array}{l}\text { Country } \\
\text { and Setting }\end{array}$ & $\begin{array}{l}\text { Methods and } \\
\text { Participants }\end{array}$ & Aim & Findings & Conclusions & $\begin{array}{l}\text { Implications for Future } \\
\text { Involvement of PLWD/ } \\
\text { Stakeholders to Achieve DFC }\end{array}$ \\
\hline$W^{39} 2018$ & $\begin{array}{l}\text { Taipei, } \\
\text { Taiwan, } \\
\text { people living } \\
\text { in community } \\
\text { attending day- } \\
\text { care or } \\
\text { neurological } \\
\text { centre. }\end{array}$ & $\begin{array}{l}\text { Qualitative } \\
\text { interviews with } 16 \\
\text { people with } \\
\text { dementia and } 20 \\
\text { family caregivers. }\end{array}$ & $\begin{array}{l}\text { To identify dementia } \\
\text { friendly } \\
\text { communities' } \\
\text { indicators and their } \\
\text { current conditions } \\
\text { in Taiwan from the } \\
\text { perspectives of } \\
\text { people with } \\
\text { dementia and } \\
\text { dementia family } \\
\text { caregivers. }\end{array}$ & $\begin{array}{l}\text { Found } 8 \text { DFC } \\
\text { indicators: DFC } \\
\text { services; DF } \\
\text { hospital; DFC } \\
\text { environment; DF } \\
\text { transportation; DF } \\
\text { stores and shops; } \\
\text { DFC members; } \\
\text { integrated dementia- } \\
\text { related information; } \\
\text { and opportunities } \\
\text { for PLWD to } \\
\text { contribute and be } \\
\text { involved in the } \\
\text { community. } \\
\text { Inclusion of those } \\
\text { with dementia not } \\
\text { expressed as } \\
\text { strongly. I PLWD } \\
\text { and } 5 \text { carers } \\
\text { expressed desire for } \\
\text { PLWD to be } \\
\text { included in the } \\
\text { community } \\
\text { activities. }\end{array}$ & $\begin{array}{l}\text { Involvement of } \\
\text { people living with } \\
\text { dementia was not } \\
\text { expressed by } \\
\text { participants. } \\
\text { Strategies to try and } \\
\text { involve people are } \\
\text { needed (but they do } \\
\text { not say what these } \\
\text { might be). } \\
\text { Also need for } \\
\text { comparative } \\
\text { research that takes } \\
\text { into account } \\
\text { different cultural } \\
\text { contexts. }\end{array}$ & $\begin{array}{l}\text { Importance of wider cultural } \\
\text { norms and understandings of } \\
\text { dementia evidence. Suggests } \\
\text { stigma more prevalent in Asian } \\
\text { countries and more work to do to } \\
\text { raise awareness. Also suggests age } \\
\text { friendly might be way forward, } \\
\text { things that enable all older people } \\
\text { to be active participants in society } \\
\text { and remove the focus on } \\
\text { dementia. }\end{array}$ \\
\hline
\end{tabular}

Abbreviations: CP, care partner; PLWD, person living with dementia; DF, dementia friendly; DFC, dementia friendly care; D-FAC, dementia friendly acute care; LTCH, long-term care homes.

with dementia as part of the decision-making process. However, research has also found ${ }^{33}$ low levels of engagement in care homes that need addressing before any attempts to create opportunities for shared decision making are possible. Swedish research ${ }^{34}$ demonstrates the need to address the communication styles of social workers to enable better discussion and therefore involvement of the person living with dementia in care decisions. In the UK, people with young-onset dementia were asked to help evaluate service commissioning and provision. ${ }^{35}$ Involving people at an early stage in the service provision process, younger or older, clearly offers an opportunity for enhanced involvement in decisions on care and support.

\section{The Value of Developing Tools to Help Service} Providers to Engage Those Living with Dementia in Care Decisions

Just as group participation could foster an engagement in decision-making activities, the development of tools in different settings to assist health professionals and others involved in supporting the person with dementia is also a method to promote engagement ${ }^{36}$ as well as a way to measure successful care outcomes. ${ }^{38,43}$ Clinicians and health and social care workers could therefore benefit from tools designed to promote engagement and involvement of those living with dementia, such as Grace and Horstmanshof's ${ }^{37}$ work to develop a tool that can be used to promote dementia literacy in Australian care settings (and arguably in other countries). But also, as Buckner et $\mathrm{al}^{38}$ suggest, tools offer one way to help ascertain if the care and support offered deliver DF outcomes for those living with dementia and, as Bennett et $\mathrm{al}^{43}$ suggest, may help to improve the experiences of the diagnostic process for those suspected of having dementia as well as the clinicians involved in diagnosing.

The Role of Awareness Raising and Education to Support the Inclusion of a Range of Stakeholders in Achieving DF Support and Care Outcomes

Studies focusing on dementia friendly initiatives in the $\mathrm{UK}^{38}$ and Taiwan ${ }^{39}$ demonstrated the need for raising awareness of dementia within society as a whole, for the 
goal of achieving better outcomes of those living with dementia to be a reality. Initiatives designed to provide education, such as Guest and Smith's ${ }^{40}$ presentation of work designed to enable caregivers to support their loved one with dementia, similarly, demonstrate the benefits of increasing knowledge to enable DF outcomes for the person living with dementia. Research ${ }^{43}$ also demonstrates a need for education for employers to support workers with dementia, and also by implication employees with care-giving responsibilities, for the principles of human rights, as they apply to the DF movement, to be protected. Thus, awareness raising and education offer a route to improving knowledge that may then change practices that better support people living with dementia in the future.

\section{The Need for Cultural and Contextual Sensitivity When Seeking to Engage Stakeholders to Achieve Positive Care Outcomes}

Engaging caregivers from African-American backgrounds required cultural sensitivity, ${ }^{40}$ and as $\mathrm{Wu}$ et al argue ${ }^{39}$ it is important to appreciate wider cultural norms and understandings of dementia where lack of awareness and understanding of dementia is prevalent. This implies a need for contextual sensitivity. This might be cultural, as in the study by $\mathrm{Wu}$ et al in Taiwan, including the culture of care in hospitals ${ }^{36,41}$ where it may not always be the norm to seek to involve and engage those with dementia. It is important therefore to recognize that cultural sensitivities are particularly important when implementing programmes in multi-cultural or cross-cultural settings, or more broadly when any sort of programme is implemented in a different culture or context to that in which it was developed. Focusing on enabling design features in different physical settings, whether hospital or care homes, ${ }^{36,41}$ may provide a practical way to enable greater engagement and participation in the day-to-day life of a care service facility for patients and residents who are accessing such services, which in turn could lead to greater involvement in dementia friendly care outcomes.

\section{Discussion}

The main aim of this review was to summarize empirical studies involving people living with dementia and other stakeholders and how to achieve dementia friendly care.

It should be noted that in papers reviewed there was a lack of common language in discussion around engaging and involving people and also what it means to meaningfully include or involve different stakeholders. Groups designed to support DFC outcomes have many names; for example, in articles from Canada alone, different terms were found for groups designed to help facilitate inclusion and engagement, namely Mutual Support Groups (Java Music Group), ${ }^{28}$ Advisory Hubs, ${ }^{29}$ CommunityBased Programming (Paul's Club) ${ }^{27}$ and Advisory Group. $^{26}$

Our review suggests a need to focus on the types of methods that can be used to involve and include people living with dementia in achieving dementia friendly care outcomes. Groups can be used to mobilize personhood, social citizenship by empowerment and social inclusion in various guises. ${ }^{25-29}$ This raises practical questions about types of group, who should be a member, how to facilitate, how to involve and how to monitor and evaluate. In addition, practitioners can be creative in how they seek to achieve shared decision making that may achieve dementia friendly care outcomes for those living with dementia. How to engage stakeholders to achieve involvement in decision making has been argued as a way to achieve positive outcomes that we would see as dementia friendly. Trying out care solutions is one way to involve PLWD and care partners in decisions that can lead to DFC outcomes, ${ }^{33}$ as is a focus on creating enhanced communication opportunities. ${ }^{34}$ Adopting co-design approaches not only provides support for people living with dementia to be fully involved in the research design, but also ensures the outcomes meet the needs of the population intended. ${ }^{30}$ Thus, achieving involvement in dementia friendly outcomes may have similar methods to those outlined in the research methods literature seeking to operationalize core principles to involve people living with dementia in research. ${ }^{19-23}$

The review demonstrates the need for tools and measures ${ }^{37,38,43}$ to assist health professionals in facilitating the inclusion of stakeholders, including those with dementia, both as a practical way to involve people,$^{20}$ but also to measure the success of involvement ${ }^{38}$ in terms of outcomes. It has also been suggested that tools offer a way to raise awareness and engagement. ${ }^{37,44}$ This mirrors research seeking to find frameworks and approaches to standardize involvement. ${ }^{19,21}$ Future work seeking to explore dementia friendly care therefore needs the frameworks informed by principles of social inclusion, shared decision making ${ }^{11,12}$ and citizenship, ${ }^{9,17,18}$ but also practical work to help practitioners know when initiatives are successful. ${ }^{7}$ 
Cultural differences in terms of emphasis on involvement of PLWD may link to cultural norms and values and awareness of dementia, ${ }^{39,40}$ in particular communities such as younger people who may have distinct needs, ${ }^{35}$ or have not accessed information about dementia easily before. ${ }^{40}$ The context where the person lives is also important; creating environments that maximize opportunities for participation has been the focus of hospital-based research, ${ }^{36,41}$ while methods to involve people living in care homes also pose distinct challenges. ${ }^{32,33}$

Creative methods have been proposed in earlier reviews, ${ }^{15,16}$ and our review found two particular examples of group work using creative methods, ${ }^{25,28}$ bearing out the potential of this approach. However, other approaches, such as education interventions, are also another way of providing the tools to promote inclusion and dementia friendly outcomes as was argued by Hebert and Scales. ${ }^{8}$ Our review found education as one successful way of engaging caregivers, with appropriate cultural sensitivity for AfricanAmerican caregivers, ${ }^{40}$ and in Scottish research a suggested approach for providing the appropriate knowledge to employers ${ }^{43}$ and other health care professionals and the general public. ${ }^{38}$

There are therefore many facets to how we might further define and, most importantly, achieve the goals of dementia friendly care policy directives ${ }^{3,4,6}$ for people living in the community or in care settings. ${ }^{7}$ Knowledge is growing regarding how the concept of dementia friendly ${ }^{8,9}$ may be operationalized and also measured, but further work is required to give a full picture of dementia friendly care in practice in different cultures and contexts.

\section{Limitations}

Our findings must be considered in terms of the limitations of the included studies (nineteen only) and the review process we followed. Some relevant studies may not have been captured by the database searches or were published after the search date. The included studies were often examples of novel initiatives in particular settings and countries. The ability to generalize findings from the studies included is therefore limited. However, the studies reviewed do clearly link to conceptual and policy developments relating to "dementia friendly", and, as such, they help to advance knowledge in an area of dementia friendly research, care and support that has been limited to date. The need to include people living with dementia in achieving dementia friendly care outcomes mirrors findings about the need for greater involvement of people living with dementia in the research process.

\section{Conclusion}

Engaging and including people living with dementia, and other stakeholders, in the quest for dementia friendly care outcomes is perhaps a natural progression from dementia friendly initiatives designed to achieve greater inclusion and integration of those living with dementia within their communities and society as a whole. Social citizenship and social inclusion are useful concepts, but they need to be operationalized within a range of approaches that are adapted to fit local contexts and needs to enable the involvement of those with dementia in achieving dementia friendly care outcomes. This review demonstrates that different methods may help attain the goal of involving people living with dementia, and other stakeholders, in achieving dementia friendly care. These include education and awareness raising initiatives, facilitating groups designed to promote and engage people living with dementia in meaningful activities that enable social citizenship to be enacted; as well as ways professionals have approached the challenge of attaining shared decision making. Tools offer a way to both measure successful outcomes, and also a mechanism for professionals to seek to engage and involve stakeholders. If such methods are developed further, then we will likely be one step closer to achieving the aim of dementia friendly care outcomes that are underpinned by social citizenship and social inclusion principles.

\section{Disclosure}

The authors report no conflicts of interest in this work.

\section{References}

1. World Health Organization. The global network for age-friendly cities and communities. looking back over the last decade, looking forward to the next; 2018. Available from: http://apps.who.int/bookorders. Accessed August 5, 2021.

2. Prince M, Wimo A, Guerchet M, Ali G, Wu Y, Prina M. World alzheimer report 2015 the global impact of dementia. alzheimer's disease international [Internet]; 2015. Available from: https://www. alz.co.uk/research/WorldAlzheimerReport2015.pdf. Accessed August $5,2021$.

3. Department of Health. Prime Minister's challenge on dementia [Internet]. London; 2012. Available from: http://dementia.dh.gov.uk/ prime-ministers-challenge-on-dementia-improvements-to-health-andcare/. Accessed August 5, 2021.

4. Department of Health. Prime Minister's challenge on dementia 2020 [Internet]. London; 2015. Available from: https://www.gov.uk/govern ment/uploads/system/uploads/attachment_data/file/414344/pmdementia2020.pdf. Accessed August 5, 2021.

5. Alzheimer's Society. Dementia 2014: Opportunity for Change. Alzheimer's Society; 2014. 
6. Alzheimer's Disease International. Dementia Friendly Communities Global developments [Internet]. London; 2017. Available from: https://www.alzint.org/u/dfc-developments.pdf. Accessed August 5, 2021.

7. Lin SY. "Dementia-friendly communities" and being dementia friendly in healthcare settings. Curr Opin Psychiatry. 2017;30 (2):145-150. doi:10.1097/YCO.0000000000000304

8. Hebert CA, Scales K. Dementia friendly initiatives: a state of the science review. Dementia. 2019;18(5):1858-1895. doi:10.1177/ 1471301217731433

9. Lin SY, Lewis FM. Dementia friendly, dementia capable, and dementia positive: concepts to prepare for the future. Gerontologist. 2015;55(2):237-244. doi:10.1093/geront/gnu122

10. Alzheimer's Disease International and World Health Organisation. A public health priority [Internet]. UK; 2012. Available from: http:// apps.who.int/iris/bitstream/handle/10665/75263/9789241564458 eng.pdf; jsessionid=6E0CF395F146E47D727BA5582C977E4A? sequence=1. Accessed August 5, 2021.

11. Wied TS, Knebel M, Tesky VA, Haberstroh J. The human right to make one's own choices - implications for supported decisionmaking in persons with dementia: a systematic review. Eur Psychol. 2019;24(2):146-158.

12. Geddis-Regan A, Errington L, Abley C, Wassall R, Exley C, Thomson R. Enhancing shared and surrogate decision making for people living with dementia: a systematic review of the effectiveness of interventions. Heal Expect. 2021;24(1):19-32.

13. Perach R, Rusted J, Harris PR, Miles E. Emotion regulation and decision-making in persons with dementia: a scoping review. Dementia. 2020;1(5):1-23.

14. Birt L, Griffiths R, Charlesworth G, et al. Maintaining social connections in dementia: a qualitative synthesis. Qual Health Res. 2020;30 (1):23-42. doi:10.1177/1049732319874782

15. Bazooband A, Courtney-Pratt H, Doherty K. Participatory community-based arts for older people living with dementia in the community: how are they evaluated? A scoping review. Geriatr Care. 2021;7(1). doi:10.4081/gc.2021.9470

16. Bellass S, Balmer A, May V, et al. Broadening the debate on creativity and dementia: a critical approach. Dementia. 2018;2:147130121876090.

17. Bartlett R, Connor DO. From personhood to citizenship: broadening the lens for dementia practice and research. J Aging Stud. 2007;21:107-118. doi:10.1016/j.jaging.2006.09.002

18. Baldwin C, Greason M. Micro-citizenship, dementia and long-term care. Dementia. 2016;15(3):289-303. doi:10.1177/1471301216638762

19. Bethell J, Pringle D, Chambers LW, et al. Patient and public involvement in identifying dementia research priorities. J Am Geriatr Soc. 2018;66(8):1608-1612. doi:10.1111/jgs.15453

20. Poland F, Charlesworth G, Leung P, Birt L. Embedding patient and public involvement: managing tacit and explicit expectations. Heal Expect. 2019;22(6):1231-1239. doi:10.1111/hex.12952

21. Walsh M, Griffiths AW. Navigating meaningful involvement: do the 'core principles for involving people with dementia in research' offer a useful framework? Dementia. 2020;19(1):101-106. doi:10.1177/ 1471301219876714

22. Stevenson M, Taylor BJ. Involving individuals with dementia as co-researchers in analysis of findings from a qualitative study. Dement Int J Soc Res. 2019;18(2):701-712. doi:10.1177/ 1471301217690904

23. Gove D, Diaz-Ponce A, Georges J, et al. Alzheimer Europe's position on involving people with dementia in research through PPI (patient and public involvement). Aging Ment Heal. 2018;22(6):723-729. doi:10.1080/13607863.2017.1317334
24. Page MJ, McKenzie JE, Bossuyt PM, et al. The PRISMA 2020 statement: an updated guideline for reporting systematic reviews. BMJ. 2021;372:2020-2021.

25. Dupuis SL, Kontos P, Mitchell G, Jonas-Simpson C, Gray J. Reclaiming citizenship through the arts. Dementia. 2016;15(3):358-380. doi:10.1177/1471301216637206

26. Mann J. Canadian charter of rights for people with dementia. Dementia. 2020;19(1):63-67. doi:10.1177/1471301219876503

27. Phinney A, Kelson E, Baumbusch J, O'Connor D, Purves B. Walking in the neighbourhood: performing social citizenship in dementia. Dementia. 2016;15(3):381-394. doi:10.1177/ 1471301216638180

28. Theurer K, Wister A, Sixsmith A, Chaudhury H, Lovegreen L. The development and evaluation of mutual support groups in long-term care Homes. J Appl Gerontol. 2014;33(4):387-415. doi:10.1177/ 0733464812446866

29. Wiersma EC, O'Connor D, Loiselle L, et al. Creating space for citizenship: the impact of group structure on validating the voices of people with dementia. Dementia. 2016;15(3):414-433. doi:10.1177/1471301216642339

30. Goeman DP, Corlis M, Swaffer K, et al. Partnering with people with dementia and their care partners, aged care service experts, policymakers and academics: a co-design process. Australas J Ageing. 2019;38(S2):53-58. doi:10.1111/ajag.12635

31. Donnelly S, Begley E, O’Brien M. How are people with dementia involved in care-planning and decision-making? An Irish social work perspective. Dementia. 2019;18(7-8):2985-3003. doi:10.1177/ 1471301218763180

32. Morgan-Brown M, Brangan J, McMahon R, Murphy B. Engagement and social interaction in dementia care settings. A call for occupational and social justice. Heal Soc Care Community. 2019;27 (2):400-408. doi:10.1111/hsc. 12658

33. Groen-van De Ven L, Smits C, De Graaff F, et al. Involvement of people with dementia in making decisions about their lives: a qualitative study that appraises shared decision-making concerning daycare. BMJ Open. 2017;7(11):1-13. doi:10.1136/bmjopen-2017-018337

34. Österholm JH, Hydén LC. Citizenship as practice: handling communication problems in encounters between persons with dementia and social workers. Dementia. 2016;15(6):1457-1473. doi:10.1177/ 1471301214563959

35. Mayrhofer AM, Mathie E, McKeown J, Goodman C, Irvine L, Natalie Hall MW. Young onset dementia: public involvement in co-designing community-based support. Aging Ment Health. 2017;22(8):933-941. doi:10.1080/13607863.2017.1334038

36. Waller S, Masterson A, Evans SC. The development of environmental assessment tools to support the creation of dementia friendly care environments: innovative practice. Dementia. 2017;16(2):226-232. doi: $10.1177 / 1471301216635829$

37. Grace S, Horstmanshof L. A realist evaluation of a regional dementia health literacy project. Heal Expect. 2019;22(3):426-434. doi:10.1111/hex.12862

38. Buckner S, Darlington N, Woodward M, et al. Dementia friendly communities in England: a scoping study. Int $J$ Geriatr Psychiatry. 2019;34(8):1235-1243. doi:10.1002/gps.5123

39. Wu SM, Huang HL, Chiu YC, et al. Dementia-friendly community indicators from the perspectives of people living with dementia and dementia-family caregivers. J Adv Nurs. 2019;75(11):2878-2889. doi: $10.1111 /$ jan. 14123

40. Guest MA, Smith MP. In our community, dementia speaks: pilot of a person-centered training targeting African-American caregivers of persons-living with dementia (innovative practice). Dementia. 2021;20(1):391-397. doi:10.1177/1471301219885784 
41. Parke B, Boltz M, Hunter KF, et al. A Scoping literature review of dementia-friendly hospital design. Gerontologist. 2017;57(4):e62-74.

42. Bennett CE, De Boos D, Moghaddam NG. Developing a tool to support diagnostic delivery of dementia. Dementia. 2019;18(78):2505-2525. doi:10.1177/1471301217750936
43. Egdell V, Cook M, Stavert J, Ritchie L, Tolson D, Danson M. Dementia in the workplace: are employers supporting employees living with dementia? Aging Ment Heal. 2021;25(1):134-141. doi:10.1080/13607863.2019.1667299

\section{Publish your work in this journal}

The Journal of Healthcare Leadership is an international, peer-reviewed, open access journal focusing on leadership for the health profession. The journal is committed to the rapid publication of research focusing on but not limited to: Healthcare policy and law;Theoretical and practical aspects healthcare delivery; Interactions between healthcare and society and evidence-based practices; Interdisciplinary decision-making;
Philosophical and ethical issues; Hazard management; Research and opinion for health leadership; Leadership assessment. The manuscript management system is completely online and includes a very quick and fair peer-review system. Visit http://www.dovepress.com/ testimonials.php to read real quotes from published authors.

Submit your manuscript here: https://www.dovepress.com/journal-of-healthcare-leadership-journal 